\title{
Human Resource Management: An Optimistic Approach at the time of Recession
}

\author{
Chandra Sekhar Patro \\ Assistant Professor, Department of Management Studies, VITS Group of Institutions, Visakhapatnam, India.
}

\begin{abstract}
Human resource management is responsible for how people are treated in organizations. It is responsible for bringing people into the organization, helping them perform their work, compensating them for their labors, and solving problems that arise. Recession presents a very difficult time for any existing organisation in today's corporate world and no company is exempted from this truth. The biggest challenge for companies and especially Human Resource in this economy downturn is to survive and to remain competitive, companies reorganized and reengineered to reduce waste. Recession poses unique challenges to the HR department. Human resources professionals often struggle to obtain the resources they need to effectively manage people in the workplace, and the difficulties that they face are augmented when economic conditions worsen. It is essential for every company to know how to implement the right metric set for this very trying period.

The present paper is conceptual in nature and finds out the major issues and challenges of human resource management at the time of recession. It provides the strategies and recommendations for not only surviving the recession but ensuring that an organization is ready to compete when expansion returns.

Keywords: Human Resource Management (HRM), Recession, Challenges, Strategies, Recruitment, Compensation
\end{abstract}

\section{Introduction}

In today's arena the most common word we come across is recession. Recession is a general slowdown in economic activity over a long period of time. A recession normally takes place when consumers lose confidence in the growth of the economy and spend less. This leads to a decreased demand for goods and services, which in turn leads to a decrease in production, lay-offs and rise in unemployment. Investors also show less interest which affects the capital and financial flows, import - export and overall Gross Domestic Product (GDP) of an economy. Managing HR during financial recession, which will eventually affect most organizations, should focus on keeping everyone calm and together through cost-effective strategies.

Human resource management is defined as a strategic and coherent approach to the management of an organization's most valued assets - the people working there who individually and collectively contribute to the achievement of its objectives. Human Resource Management is one of the most essential responsibilities of each and every manager in an organization. It purely involves people for getting things done through them in an organized manner. This comprises a list of activities and one important factor among them would be placing right person for the right job, recruiting and training them in their specialization and also assisting employees for benefits, rewards and other policies.

Human resource plays a bigger role during tough times than during periods of prosperity and growth. In co-operation with management and the leaders within the organization, the HR department has to implement sound, consistent strategies to help everyone through the recession lows. The first order of the organization would be to calm down everyone and prevent from panicking as much as possible. Scrambling and hurrying to slap some sort of message to the organization might be more counterproductive than helpful.

\section{Objectives Of The Study}

a) To find out the various human resource management challenges at the time of recession.

b) To recommend the appropriate strategies to meet the human resource management challenges during recession.

\section{HR Challenges Caused By Recession}

There are a lot of studies on human resource management but very little on human resource management at the time of recession. Recession gives lots of challenges to Human Resource management. In addition to the challenges they face when general economic conditions are poor, HR managers are confronted with many problems when souring market trends directly impact their companies. The HR Recession Initiatives 
have to be focused on the analysis of the current situation and the unlocking the potential for the future growth. Few of the Challenges can be listed as:

Freeze in the recruitment process: The recruitment freeze is the first challenge of HR department to be affected by the recession. As the top management has to keep the cash flow under the control, the recruitment freeze is the first logical decision. After the recruitment freeze the organization has to clearly decide about its priorities as the organization does not carry additional people on its payroll. The top management has to decide about the new strategy and the management is allowed to hire just the missing skills and competencies.

Reduction in the strength of the organization: Layoff is the temporary suspension or permanent termination of employment of an employee for business reasons, such as the slow-down or interruption in work. It is another challenge that has to be faced by the top management. It takes all of a management team's resources, including both business acumen and humanity. The extreme difficult decision is who must be laid off, how much notice they will be given, and how far the company will go to help the laid-off employee find another job are given less than adequate attention.

Cut down in training and development programmes: The training and development is another HR Process to be affected by the recession. The focus of organizations must be on reducing costs and training may be one of the functions where budgets may get impacted majorly. The management has to decide about the cuts in the investments and Human Resources have to find a way, how to keep the knowledge in the organization. The company can survive without training and development for a limited period of time. The cost savings can be huge and the organization feels no impact of the lower training budget. But the period has to be really limited as the organization does not lose the talents and the internal know how.

Re-design in compensation and benefit schemes: The compensation and benefit schemes are also heavily affected by the recession. Compensation is payment to an employee in return for their contribution to the organization, that is, for doing their job. Benefits are forms of value, other than payment, that are provided to the employee in return for their contribution to the organization, that is, for doing their job. The recession makes a huge pressure on the overall costs of the organization and the compensation strategy can easily change the position of the organization on the pay market. HR managers may find it difficult to design compensation programs that adequately provide employees with an equitable level of compensation and an incentive to perform effectively.

Barriers in the working environment: During a recession, a reduction in available resources can significantly affect a company's strategy for the design of jobs and working environment. When a company cuts labor costs through either a workforce reduction or a reorganization of its operating structure, there is a change in the tasks and responsibilities associated with a number of positions. This has various effects on a company, including increased risk that employees may not possess the skills and knowledge requisite for completing their assigned tasks, uncertainty among employees regarding their roles in the organization, and the potential for overwork of employees as they take on more assignments.

Effective Performance Management: A company's performance management process is affected during a recession primarily by the same factors that influence a company's job design, training and development, and compensation processes. Performance management in recession needs utmost care by HR department as it gives many challenges not only to employees but the top management are also under pressure to seek some new opportunities to meet expenses. At the time of recession the stakeholders' value is also in question. In such situation the challenges for performance management increase drastically. When employee needs become more volatile and their motivations change, employers must adjust their methods for assessing employee performance and providing feedback to match the characteristics of their jobs.

\section{Framework To Meet The Challenges Of HRM In Recession}

An economic recession can have many significant effects on HRM processes and on its HR managers' ability to effectively govern them. A Framework to meet the challenges of human resource management at the time of recession: 


\begin{tabular}{|c|c|}
\hline $\begin{array}{l}\text { HR Challenges in Recession } \\
\checkmark \text { Freeze in the recruitment process } \\
\checkmark \text { Reduction in the strength of the } \\
\text { organization } \\
\checkmark \quad \text { Cut down in training and } \\
\text { development programmes } \\
\checkmark \text { Re-design in compensation and } \\
\text { benefit schemes } \\
\checkmark \text { Barriers in the working } \\
\text { environment } \\
\text { Effective } \\
\text { Management }\end{array}$ & 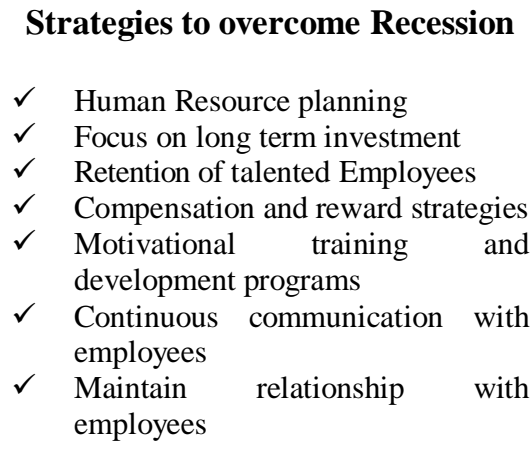 \\
\hline
\end{tabular}

\section{Strategies To Be Adopted During Recession By A Hr Manager}

The recession is an opportunity for HR professionals to step and contribute strategically. Human Resource Management must play a more strategic role in the success of an organization. However, by utilizing an approach based on maximizing the benefits received from HRM spending, companies can implement practices that will enable them to not only survive an economic downturn but to develop unique, strategic positions and gain a competitive advantage over other companies. The following are the strategies that can be followed by a HR manager during the recession:

Human Resource planning: The HR managers should give greater priority to succession planning than to their broader aggregate planning initiatives because such an investment allocation will provide greater returns. A company that plans for succession effectively will more quickly identify the developmental needs of top performers which will lead to better job design and more effective training and development programs. In order to effectively improve its succession planning processes, a company's most senior managers should dedicate more time to updating succession plans. Though aggregate planning is less crucial than succession planning during a recession, strategic HR managers with sufficient resources can take an innovative approach to identifying potential gaps in talent based on the organization's predicted needs. A company can employ unique strategies for recruiting that enable it to gain advantages over other firms when hiring both during and after a recession.

Focus on long term investment: The most critical and most difficult consideration that a company must make when managing employees through a recession is how to balance its current need to cut costs with its long-term desire to achieve strategic results. The first step that HR manager should take in managing a human resource investment is to recognize that not all investments are created equal. A HR manager has to estimate the returns for each functional area of the business unit and review both how the company is allocating its aggregate resources and how each function is contributing to overall investment returns. Alternatively, the company may identify an area where returns are poor but a greater level of investment will foster an increase in scale and ultimately efficiencies. Periodically, the HR manager and top management should discuss about the strategies for improving overall returns through a reallocation of funds. The ultimate output from these discussions should be a strategic plan for increasing the return on the HRM portfolio.

Retention of talented Employees: It is no secret that the high talented employees or multi-skilled employees are most critical to a company's success. Companies can find one way to decrease recruitment cost is to have multiskilled employees. Retention of multi-skilled employees help to reduce manpower dependence, and the overall sum of all the multi-skilled employees is greater than the same number of equal number of specialist. The advanced knowledge, experience, and skills that such employees have represent the most viable strategic competitive advantage that a successful organization has. Talented employees continuously need new challenges and goals they can achieve, and a continuous supply of information and resources they can use to solve business problems. 
Compensation and reward strategies: Compensation practices should be revised during a recession so that they are adjusted with the needs of employees. Where the incentive based bonuses may be too costly for an organisation to pay they can use other strategies. The companies can implement flexible work schedules which not only provide a desired benefit to employees but may also reduce the costs of the company. Investment in healthcare benefits can allow a company to achieve a competitive advantage that it can sustain after the recession, enabling the organization to more easily attract talented employees when labor demand improves. Stress management may also help an employer to reduce its long-term employee medical costs. Such strategies that can both maximize employee return and decrease employee cost will provide significantly improved returns on HRM investments.

Motivational training and development programs: HRM professionals should give strong consideration to increasing resources allocated to training and development during a downturn. The managers should design training and development programs that are in line with employees' needs and the skills required to perform job tasks. This can be more easily accomplished if managers first ensure that workers and their associated job roles have the appropriate fit as previously recommended. Lack of motivation in employees will not improve organization's business in any way. Motivation can be either intrinsic which is self-generated that will influence the employees or extrinsic which is all about rewards, promotion and so on. Effective training and development programs will also consider how each generation of employees uniquely prioritizes its needs. An employer should utilize training and development programs that improve the workplace flexibility of its managers as well.

Continuous communication with employees: Communication should definitely be one of the focus points during the recession metrics. Open communication should be administered because without this, the informal grapevine would then be the ultimate source of the company. Communication minimizes rumors, which if not managed properly, can lead to grave consequences. The face-to-face communication such as briefings by managers and small group meetings is a more appropriate technique for dealing with a subject as traumatic as downsizing.

Maintain relationship with employees: Employee Relations involves the body of work concerned with maintaining employer-employee relationships that contribute to satisfactory productivity, motivation, and morale. Employee's relations can be encouraged to reduce the overall cost of the organization by involving employees. It is important that how HR manages the relation with employees so that employee should feel proud and gain a sense of ownership. In order to get through the rough times and keeping the right people actively engaged, performing well, and keeping them on board requires business owners of all sizes to use all the tools at their disposal.

\section{Recommendations}

During recession, HR manager has to act as a democratic leader. He should also try to combine the organizational and employees interest and adopt situational leadership style as well as humanistic approach for leading the employees to achieve the organization goals. Following are few recommendations for HR Manager to deal with employees during recession:

1. The HR managers should focus on the succession and contingency plans.

2. Maintaining employer-employee relationships that contribute to satisfactory productivity, motivation and morale.

3. Rewards and recognition is one of the best tools to motivate employees.

4. Flow of Communicate should be from top to down that will help in making conducive atmosphere within the organization

5. Identifying the real key employees and focus on the continual development of employee knowledge to retain them.

6. Human Resources have to be ready to provide necessary data to the Organization, solving the initial problems with the recession.

7. Design new efficient HR policies, processes and procedures to ensure that they are purposeful and contribute directly to the success of the company with minimum cost.

8. Consistent and committed leadership helps employees overcome organizational change caused by downsizing.

9. Increase brainstorming sessions with top management and contribute in their strategic planning.

10. Review the employee performance evaluations to determine the key people that the company cannot afford to lose. 


\section{Conclusion}

Human Resource Management must play a highly proactive role in managing the issues of global recession by helping organization to enhance their abilities to learn and collaborates, manage diversity, ambiguity and complexity. Human Resource Management is responsible to manage the human resource of the corporate to maximize the productivity, efficiency at minimal cost and maximize profit. Recession has threatened the corporate to hire in bulk and have wide bench strength. It has also tightened the measures for human resource management. At the time of recession and post recession, the things become complicated for corporations. However the challenges of human resource management differ from industry to industry and firm to firm. The recession is the temporary economic climate of the business world. The recession is a good opportunity for Human Resources to introduce the changes to the organization. It will be changed through more productivity at minimal cost and maximize profit at moderate price of products in business. But the reaction of HR has to be quick as the internal opposition has no chance to form their forces.

\section{References}

[1] Emerging issues in Human Resource Management by Pramod Vernia publish and IBH publish (p) Ltd.,

[2] Human Resource Management by by S.S.Khanka

[3] A Handbook of Human Resource Management Practice 10th Ed (2006) by Michael Armstrong

[4] Mittal, Arun (2007), “A Study of people productivity in HRM”, Promotion Productivity, Delhi productivity council, Delhi.

[5] HRM guide.2009.compensation strategy in recession. August 13:08

[6] http://www.ipsosmori.com/Assets/Docs/Publications/ERM\%20Recession.pdf

[7] http://hr-horizons.blogspot.in/2009/01/managing-hr-inrecession.html

[8] ICMR.2009 .Employee downsizing. Center for management and research, 23(2):4-5.

[9] Henri J.F.(2004), Performance measurement \& organizational effectiveness: Bridging the gap. Management Finance. Vol. $30: 93$-123.

[10] Economic Times.2009.HR working in Recession. September 09.09

[11] Managing HR in Recession : HR Article by GlobalHunt

[12] HR has to Challenge the Challenges, HRD News Letter Jan'09Vol.24.iss.10 p.22

[13] www.recession.org

\section{About Author}

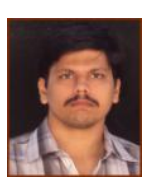

Mr. Chandra Sekhar Patro working as Assistant Professor in the Department of Management Studies in VITS Group of Institutions, Visakhapatnam, India. He completed M.Com from Andhra University, MFM from Pondicherry University and MBA (HR \& Finance) from JNT University. He has 7years of total experience. He has good knowledge in HR and Finance subjects.
} 